\title{
PERBANDINGAN KADAR GLUKOSA DARAH PADA SAMPEL YANG MENGALAMI VARIASI LAMA PENUNDAAN PEMISAHAN
}

The comparison of blood glucose levels in samples experiencing long variations of
delayed separation

\author{
Novie Trisyani ${ }^{1}$, Syahida Djasang ${ }^{2},{\text { Zulfian } \text { Armah }^{3}}^{3}$ \\ ${ }^{1}$ Jurusan Analis Kesehatan Poltekkes Kemenkes Manado \\ ${ }^{2,3}$ Jurusan Analis Kesehatan Poltekkes Kemenkes Makassar
}

Korespondensi: novietrisyani@gmail.com

\begin{abstract}
The quality of the results clinical laboratory examination, issued must be guaranteed reliability and quality, both the quality of the product and the quality of service so that reach the expectations and satisfaction of patients or doctor. The problemsthat often occur in laboratory is unworked direct examinations of collected sample. The samples was delay for the reasons. Bood glucose levels can make a decomposition or glycolysis proses. The purpose of this research to know a present or not the different of blood glucose levels which experiencing long variation of delay separation. The type of this research is quasi experiment for blood glucose examination, collecting sample use simple random sampling and it found 10 samples on February $20^{\text {th }}$ - march $6^{\text {th }} 2019$ in Clinical Chemistry of Poltekkes Kemenkes Manado. Based on result of anova test obtained the value of $F$ count 7.130 by significance ( $p$ ) about $0.003<0.05$, it means the results are significan decreased. The concluded is that occur the different blood glucose levels on sample which experiencing long variation of delay separation. Hoped for the Medical Laboratory Technic to pay attention for pre-analytical phase, the obtained sample immediately proses and separated from the erythrocyte and immediately conduct an examination.
\end{abstract}

Keywords : Blood glucose, delay separation, pre-analytical

\begin{abstract}
ABSTRAK
Mutu hasil pemeriksaan laboratorium klinik yang dikeluarkan harus terjamin keandalan dan kualitasnya, baik kualitas produknya maupun kualitas pelayanannya sehingga memenuhi harapan atau kepuasan pasien atau dokter. Permasalahan yang sering terjadi di laboratorium adalah pengumpulan sampel yang tidak dikerjakan dengan pemeriksaan langsung. Sampel mengalami penundaan dengan alasan-alasan tertentu. Kadar glukosa darah dapat mengalami proses penguraian atau proses glikolisis. Penelitian ini bertujuan Untuk mengetahui ada tidaknya perbedaan Kadar Glukosa pada sampel yang mengalami variasi lama penundaan pemisahan. Jenis penelitian ini adalah eksperimen semu dengan melakukan pemeriksaan glukosa darah, dengan teknik pengambilan sampel menggunakan cara simple random sampling didapatkan sebanyak 10 sampel pada tanggal 20 Februari - 6 maret 2019 di Laboratorium Kimia Klinik Poltekkes Kemenkes Manado. Berdasarkan hasil analisis Uji Anova diperoleh harga F hitung 7.130 dengan signifikansi (p) sebesar $0.003<0.05$, yang artinya didapatkan hasil penurunan yang signifikan. Sehingga dapat disimpulkan terdapat perbedaan kadar
\end{abstract}


glukosa darah pada sampel yang mengalami variasi lama penundaan pemisahan. Diharapkan bagi para Tenaga Laboratorium Medik dapat memperhatikan tahapan pra analitik, agar sampel yang didapat segera diproses dan dipisahkan dari sel darah merah dan segera melakukan pemeriksaan

Kata kunci : Glukosa Darah, Penundaan Pemisahan, Pra Analitik

\section{PENDAHULUAN}

Pemeriksaan laboratorium klinik merupakan salah satu bentuk pelayanan kesehatan yang penting dalam membantu menegakkan diagnosa dan terapi suatu penyakit. Penyakit tidak hanya dapat diketahui dari keluhan pasien dan gejala-gejala klinik yang tampak, sehingga pemeriksaan laboratorium mutlak diperlukan oleh dokter maupun petugas kesehatan untuk memastikan diagnosa. Mutu hasil pemeriksaan yang dikeluarkan harus terjamin keandalan dan kualitasnya, baik kualitas produknya maupun kualitas pelayanannya sehingga memenuhi harapan atau kepuasan pasien atau dokter (Scanlon, 2006). Agar dapat memberikan hasil pemeriksaan yang berkualitas, perlu dilakukan program pengendalian mutu terpadu, yang mencakup pengendalian mutu tahap pre analitik, tahap analitik dan pasca analitik (Smart living, 2008).

Pengumpulan darah dalam tabung bekuan untuk analisis kimiawi serum memungkinkan terjadinya metabolisme glukosa dalam sampel oleh sel-sel darah sampai terjadi pemisahan melalui sentrifugasi. Hitung sel darah yang sangat tinggi dapat menyebabkan glikolisis berlebihan dalam sampel sehingga terjadi penurunan kadar glukosa yang bermakna. Suhu lingkungan tempat darah disimpan sebelum pemisahan juga mempengaruhi tingkat glikolisis. Pada suhu lemari pendingin glukosa tetap stabil selama beberapa jam didalam darah. Pada suhu kamar diperkirakan terjadi penurunan 1 sampai
$2 \%$ glukosa/jam (Sacher, 2004). Menurut Agung A,dkk (JKD,2017) bahwa kadar glukosa pada sampel serum bertahan sebesar $94,97 \%$ dari kadar awalnya setelah penundaan 4 jam, kemudian menurun hingga 85,44\% setelah 8 jam penundaan.

Begitupun dengan hasil penelitian yang dikemukakan oleh Hilda,dkk (2011), dimana terdapat perbedaan yang signifikan antara lama pemeriksaan yang ditunda pada 15,30 (0.9258 mg\%), 45 (1.84 mg\%) dan 60 menit $(2.722 \mathrm{mg} \%)$ dengan penurunan kadar glukosa darah, semakin lama pemeriksaan ditunda, semakin rendah kadar glukosa.

Berdasarkan masalah diatas maka peneliti berkeinginan untuk melakukan penelitian tentang "Perbandingan Kadar Glukosa Pada Sampel Yang Mengalami Variasi Lama Penundaan Pemisahan".

\section{METODE}

Peneltian ini dilakukan pada bulan Februari hingga Maret 2019 di Laboratorium Kimia Klinik Poltekkes Kemenkes Manado. Populasi pada penelitian ini adalah mahasiswa D. III tingkat 2 Analis Kesehatan Poltekkes Kemenkes Manado yang berjumlah sebanyak 10 orang. Teknik pengambilan sampel yang digunakan terlebih dahulu disesuaikan dengan kriteria inklusi maupun eksklusi, setelah didapatkan jumlah sampel yang memenuhi syarat tersebut yaitu sebanyak 26 orang, kemudian dilakukan pengambilan sampling menggunakan sistem simple random sampling, dimana 
prinsip mekanisme teknik acak sederhana dilakukan seperti undian, yaitu semua individu berpeluang untuk diambil sebagai sampel. Penentuan jumlah sampel menggunakan rumus Federer, dari perhitungan rumus tersebut didapatkan jumlah sampel sebanyak 10 orang. Dari ke sepuluh sampel tersebut dilakukan pengambilan darah dilakukan pemeriksaan kadar glukosa darah sewaktu dengan tiga (3) perlakuan yang berbeda, yaitu sampel pertama sebagai kontrol dimana satu jam setelah dilakukan pengambilan darah, segera dipisahkan dan dilakukan pemeriksaan, dan selanjutnya pada perlakuan ke dua dan ke tiga ditunda pemisahannya selama 2 jam dan 3 jam.

Proses pada pengambilan darah, setiap satu orang sampel diambil $3 \mathrm{ml}$ darah, yang kemudian dipisahkan dalam 3 tabung masing-masing sebanyak $1 \mathrm{ml}$ darah. Suhu ruang tempat penelitian merupakan salah satu faktor pengganggu, dan suhu ruang pada saat penelitian adalah antara $18-25^{\circ} \mathrm{C}$, sehingga suhu ruang tersebut dapat dikendalikan. Pengambilan darah pada mahasiswa/i dilakukan pada saat jam istirahat dari perkuliahan. Sebelum dilakukan pemeriksaan darah sampel, terlebih dahulu dilakukan pemeriksaan dengan menggunakan kontrol serum level I untuk menjamin hasil pemeriksaan valid.

Hasil perlakuan terhadap serum dan pemeriksaan disajikan dalam bentuk tabel kemudian dianalisa secara uji statistik menggunakan uji Anova satu arah

\section{HASIL}

Sampel serum yang didapatkan dari mahasiswa sebanyak 10 orang, dimana frekuensi umur individu sebanyak 70\% adalah umur 19-20 tahun dan diantaranya subyek berjenis kelamin laki-laki (40\%) dan 6 subyek berjenis kelamin perempuan (60\%), dapat dilihat pada tabel 1.1

Data yang diperoleh dari penelitian yang telah dilakukan dapat dideskripsikan sebagai berikut, pemeriksaan glukosa pada penundaan pemisahan 1 jam (kontrol) didapatkan hasil nilai tengah sebesar $86.50 \mathrm{mg} / \mathrm{dL}$ dengan nilai minimum $78 \mathrm{mg} / \mathrm{dL}$ dan nilai maksimum $98 \mathrm{mg} / \mathrm{dL}$ Pemeriksaan glukosa pada penundaan pemisahan selama 2 jam didapatkan hasil rata-rata $81.60 \pm 5.948 \mathrm{mg} / \mathrm{dL}$. Pemeriksaan glukosa pada penundaan pemisahan selama 3 jam didapatkan hasil rata-rata $77.40 \pm 5.967 \mathrm{mg} / \mathrm{dL}$, yang dapat dilihat pada tabel 1.2

Langkah pertama dalam analisis hipotesis adalah uji normalitas. Uji ini dilakukan untuk mengetahui apakah data yang ada terdistribusi normal atau tidak.

Berdasarkan uji normalitas yang diperoleh menggunakan data Shapiro wilk dimana nilai signifikansi untuk hasil pemeriksaan glukosa darah baik penundaan pemisahan 1 jam sebesar 0.964, dan nilai signifikansi penundaan pemisahan 2 jam sebesar 0.971, begitupun dengan nilai signifikansi penundaan pemisahan 3 jam sebesar 0.0991, dimana nilai signifikansi 3 perlakuan > 0.05 yang artinya sebaran data tersebut adalah berdistribusi normal.

Berdasarkan hasil uji Homogenitas varian antar kelompok perlakuan dengan menggunakan Analisis of Varian (ANOVA) satu jalur diperoleh signifikansi $0.995>0.05$, yang artinya varian antar kelompok adalah homogen. Uji Anova satu arah

Berdasarkan hasil analisis Uji Anova diperoleh harga $\mathrm{F}$ hitung 7.130 dengan signifikansi sebesar 0.003 < 0.05, maka H0 ditolak dan Ha diterima artinya terdapat perbedaan kadar glukosa darah pada sampel yang 
mengalami variasi lama penundaan pemisahan.

\section{PEMBAHASAN}

Glikolisis merupakan salah satu dari empat jalur metabolisme glukosa. Glikolisis adalah perubahan glukosa menjadi asam piruvat. Glikolisis dapat dipandang sebagai tahap pertama proses respirasi (aerobic) didalam sel yang terjadi didalam sitosol, dimana glukosa dioksidasi menjadi asam piruvat atau sebagai proses pembentukan energi (ATP) dalam keadaan anaerobik. Glukosa kemudian dioksidasi menjadi asam piruvat, yang kemudian dirubah menjadi asam laktat dari proses glikolisis ini akan menghasilkan 2 ATP. Hati dapat mengubah asam laktat tersebut menjadi glukosa (Deddy Muchtadi, 2009).

Pengumpulan darah dalam tabung untuk analisis kimia bekuan serum memungkinkan metabolisme glukosa dalam sampel dengan sel darah sampai dipisahkan dengan sentrifugasi. Sel darah merah, misalnya, tidak memerlukan insulin untuk asupan glukosa dari darah. Lebih tinggi dari jumlah normal jumlah darah putih atau sel darah merah dapat menyebabkan glikolisis yang berlebihan di sampel dengan pengurangan substansial tingkat glukosa jika sampel tidak diproses dengan cepat. Suhu lingkungan di mana sampel darah disimpan sebelum pemusingan dan pemisahan plasma / serum juga mempengaruhi kadar glukosa. Pada suhu lemari es, glukosa tetap relatif stabil selama beberapa jam dalam sampel darah. Pada suhu kamar $\left(25^{\circ} \mathrm{C}\right)$, kehilangan 1 sampai $2 \%$ dari total per jam glukosa harus diharapkan dalam sampel darah keseluruhan. Penurunan glukosa ini dapat dicegah dengan menggunakan tabung dengan antikoagulan $\mathrm{Na}$ Fluorida (tutup abu$\mathrm{abu}$, fluoride dapat menghambat terjadinya glikolisis. Dan digunakan ketika darah akan diangkut dari satu laboratorium rumah sakit lain untuk pengukuran glukosa. Tabung pemisah serum bertutup merah juga mempertahankan kadar glukosa dalam sampel setelah tabung disentrifugasi untuk memisahkan serum dari sel (Sacher, 2004).

Hasil penelitian ini menunjukkan bahwa terjadi penurunan yang signifikan pada sampel yang mengalami variasi lama penundaan pemisahan, dikarenakan terjadi glikolisis dalam sel yang terdapat pada tabung darah. Sesuai dengan hasil para peneliti sebelumnya, hanya saja pada penelitian ini terdapat perbedaan persentase penurunan kadar gukosa setiap jamnya dibandingkan dengan peneliti sebelumnya.

Dalam penelitian ini didapatkan hasil penurunan yang signifikan, jika dibandingkan dengan sampel yang dilakukan pemisahan setelah 1 jam pengambilan darah sebagai kontrolnya, maka telah terjadi penurunan kadar glukosa sebesar $6,52 \%$ pada 2 jam pertama saat pengambilan darah, dan $11,34 \%$ terjadi penurunan kadar glukosa darah setelah 3 jam terhitung setelah pengambilan darah pada sejumlah populasi sampel yaitu sebanyak 10 orang. Sehingga dapat diartikan bahwa pada penelitian ini terjadi penurunan sebesar $4-6 \%$ per jam nya, sesuai dengan teori yang dikemukakan oleh Hasan, Irsan (2006).

\section{KESIMPULAN}

Berdasarkan hasil penelitian tentang "Perbandingan Kadar Glukosa Darah Pada Sampel yang Mengalami Variasi Lama Penundaan Pemisahan" di Laboratorium Kimia Klinik Poltekkes Kemenkes Manado Jurusan Analis Kesehatan, maka diperoleh suatu kesimpulan bahwa terdapat perbedaan 
yang signifikan penurunan kadar Glukosa darah sebesar $4-6 \%$ per jam nya, pada sampel yang mengalami variasi lama penundaan pemisahan

\section{SARAN}

1. Diharapkan bagi para Tenaga Laboratorium Medik dapat memperhatikan tahapan pra analitik, agar sampel yang didapat segera diproses dan dipisahkan dari sel darah merah dan segera melakukan pemeriksaan.

2. Diharapkan bagi peneliti selanjutnya dapat mengembangkan penelitian untuk menganalisa lebih mendalam mengenai hubungan faktor penyebab glikolisis sel seperti jumlah sel eritrosit dan sel lekosit yang meningkat, suhu, waktu dan jumlah sampel yang lebih besar.

\section{UCAPAN TERIMA KASIH}

1. Poltekkes Kemenkes Manado

2. Poltekkes Kemenkes Makassar

3. PT. Multilab Utama Manado yang telah mensuport berupa maintenance dan kalibrasi pada alat BTS-350

\section{DAFTAR PUSTAKA}

Agung A, Retnoningrum D., Edward I.K.S.L., 2017. Perbedaan Kadar Glukosa Serum dan Plasma Natrium Fluoride $(\mathrm{NaF})$ dengan Penundaan Pemeriksaan. Jurnal Kedokteran Diponegoro,
Semarang.

Anonim, 2008. Bagaimana Prodia Memberikan Hasil Pemeriksaan Yang Berkualitas, ed. 14. Smart Living. Jakarta, The Writers' Guild.

Deddy Muchtadi, M.S., 2009. Pengantar Ilmu Gizi. Alfabeta, Bandung

Hasan, Irshan. 2006. Seminar \& Road Show Prodia, Bijak Mengelola Kesehatan Kesejahteraan Keluarga. http://medicastore.com/index.p $\mathrm{hp}$ ?mod=printPage\&page $=$ sem inar\&id $=5$

Hilda, Harlita T.D., Hartono A.R , 2011. Pengaruh Waktu Terhadap Hasil Pemeriksaan Kadar Glukosa Darah pada Penderita Diabetes Melitus. Jurnal Husada Mahakam vol. III No.2, hlm. 45-94, Poltekkes Kemenkes Kaltim.

Sacher, R. A. and McPherson, R. A., 2004. Tinjauan Klinis Hasil Pemeriksaan Laboratorium, edisi 11, Buku Kedokteran EGC, Jakarta.

Scanlon, V. C., 2006. Buku Ajar Anatomi dan Fisiologi Edisi 3. Buku Kedokteran EGC, Jakarta. 
Tabel 1.1 Distribusi Jenis Kelamin.

\begin{tabular}{ll|c|c|c|c}
\hline & & $\mathrm{F}$ & $\%$ & Valid \% & Cumulative \% \\
\hline Valid & LAKI-LAKI & 4 & 40.0 & 40.0 & 40.0 \\
& PEREMPUAN & 6 & 60.0 & 60.0 & 100.0 \\
& Total & 10 & 100.0 & 100.0 & \\
\hline
\end{tabular}

(sumber data primer)

Tabel 1.2 Distribusi Hasil Pemeriksaan Kadar Glukosa Yang Mengalami Penundaan Pemisahan

\begin{tabular}{l|c|c|c}
\hline \multicolumn{1}{c|}{ Perlakuan } & Mean (SD) & $\begin{array}{c}\text { Median } \\
\text { (Min-Max) }\end{array}$ & $\begin{array}{c}\text { Perbedaan Kadar } \\
\text { Glukosa }\end{array}$ \\
\hline $\begin{array}{l}\text { Penundaan 1 jam } \\
\text { (Kontrol) }\end{array}$ & $87.30(5.736)$ & $\begin{array}{c}86.50 \\
(78-98)\end{array}$ & - \\
\hline Penundaan 2 jam & $81.60(5.948)$ & $\begin{array}{c}81.50 \\
(72-93)\end{array}$ & $5.7(6.52 \%)$ \\
\hline Penundaan 3 jam & $77.40(5.967)$ & $\begin{array}{c}78 \\
(67-88)\end{array}$ & $9.9(11.34 \%)$ \\
\hline
\end{tabular}

Tabel 1.3 Uji normalitas

\begin{tabular}{l|l|c|c|c}
\hline \multirow{3}{*}{} & \multicolumn{3}{|c}{ Shapiro-Wilk } \\
\cline { 3 - 5 } & Penundaan & Statistic & df & Sig. \\
\hline Hasil & Penundaan 1 jam & .980 & 10 & .964 \\
& penundaan 2 jam & .981 & 10 & .971 \\
& penundaan 3 jam & .987 & 10 & .991 \\
\hline
\end{tabular}

Tabel 1.4 Uji Homogenitas

\begin{tabular}{l|l|l|l}
\hline Levene Statistic & df1 & df2 & Sig. \\
\hline .005 & 2 & 27 & .995 \\
\hline
\end{tabular}

Tabel 1.5 hasil uji ANOVA

\begin{tabular}{l|l|l|l|l|l}
\hline & Sum of Squares & df & Mean Square & F & Sig. \\
\hline Between Groups & 493.800 & 2 & 246.900 & 7.130 & .003 \\
Within Groups & 934.900 & 27 & 34.626 & & \\
Total & 1428.700 & 29 & & & \\
\hline
\end{tabular}

